Humboldt to Brinton, shows that the Mexicans, unlike the various barbarous tribes of North American Indians, belong undoubtedly to a superior stock, and as evident proof of this there stands out in bold relief the immortal monuments which vividly interpret their remarkable advance in the arts, literature and science. But if, as the result of conquest, the energy of the Mexican race has been temporarily paralyzed as has similarly been the case with other nations of antiquity, like the Greeks and Romans for instance, my people, on account of physical, intellectual or moral characteristics, should not, can not be placed on the level with any of the truly inferior races. But what is to be expected from those blinded by prejudices, from those who are sadly wanting in logical reasoning? People there are so biased as to be carried to ridiculous extremes; people who, again, like unprincipled politicians of to-day, will say and do anything, no matter how degrading, for the sake of notoriety, or to gain certain selfish ends. The question is now being discussed in this State, for example, as to whether the Mexican is eligible or not to American citizenship! And why? On account of his origin. For it is claimed that he is neither a white man nor a negro! And what of it? But I will not enter into further consideration of so trivial a matter.

And as for the standing of medical science and the profession in Mexico, I will only say that serious observation by unbiased minds will certainly convey a better general impression of those matters than the thoughtless, ungenerous, not to say false, statements made by Drs. Warfield and Ward.

In conclusion, I sincerely trust that a large contingent of American physicians may attend the Congress at the City of Mexico on November next and, laying aside all prejudices of race or otber prejudices (prejudices of any kind should not be entertained by scientific medical men), let those physicians see and study for themselves the characteristics of the Mexicans as an ethnologic element, and note whether they are not as capable of achievement in all the higher pursuits as our brethren north of the Rio Grande. I can assure the American physicians attending the Congress that, on their return, they will not imitate the conduct of Drs. Warfield and Ward (as they will have no true cause for so doing), or like a certain Mr. Lancaster of this State of Texas, say that the Mexican belongs to "a race more uncouth than the negro, less intelligent, less friendly, and more like a savage." Very truly yours,

$$
\text { David Cerna, M.D., Ph.D. }
$$

\section{The Antivivisection Bill and the Senate.}

The following informal and unofficial correspondence is self explanatory:

\section{The Hon. S. M. Cullom, U. S. Senate.}

Chicago, May 14, 1896.

Dear Mr. Senator:--The views of the AMERICAN Medical Association, and of the profession generally, are so opposed to the bill now pending in the Senate for the restriction of vivisection that $I$ venture to ask your powerful aid in defeating the measure, which $\mathrm{I}$ understand has in the Senate no less adroit an advocate than Senator Gallinger.

Nearly every notable advance in the science of physiology, $i . e .$, knowledge of the functions of the organs of the body, and the most valuable facts in connection with animal chemistry, and the effects of medicines, have been made and recorded in consequence of experimentation upon the lower animals, and we therefore look with alarm upon a bill which if it become a law, will relegate science in this country to a back corner. The people who make the greatest outcry are those who know least about the subject as a rule, and should their arguments be brought to a legitimate conclusion, we should close up the butcher shops and become vegetarians. I have great sym. pathy with our cattle, but at the same time I have an appetite for roast beef which vegetarian sentiment and a diet of turnips and cabbage will not appease. When our antivivisectionists rise up and demand the passage of laws that they insist are for the protection of animals, let us insist that they prove that they are vegetarians and that by no weakness they sacrifice one of the lower animals to man's needs. Let us banish red snapper and pompano from the menu in the Senate restaurant, and as for the succulent canvas-back, the reed bird and the terrapin, let the gourmet die the death, unless he be willing to regale himself on beans and Boston brown bread instead. I can not conceive that the mighty fisherman from Maine or the gallant Nimrod from Missouri would consent to such a bill. The shade of Isaak Walton would rise in wrath to see any of his devoted followers forsake his paths at the first onslaught of a vegetarian enemy.

Can't you help defeat this imbecile offspring of the longhaired traveling physiologists, and let our laboratories teach the students in peace, unvexed by the nonsense of these dyspeptic sentimentalists?

Faithfully your friend, JoHN B. HamiLton, M. D.

\section{United States Senate.}

Washington, D. C., May 18, 1896.

Dr. John B. Hamilton, American Medical Association, Chicago, Ill.- Your favor of the 14th inst. is received and noted. I know so little about medical legislation, or the proper legislation in the interest of medical science and practice, that I have generally allowed such matters to go along without much interest upon my part. All I can say is, that I am in favor of whatever legislation may seem necessary and fair in the interest and progress of science and practice of medicine and the development of knowledge in the direction of physiology or a knowledge of the functions of the body. Just what the bill referred to by you means, I do not know, but I will try to give it attention.

I should be against any legislation that would interfere with the privilege of satisfying the appetite with a good roast beef, or mutton, or chicken, or duck, or terrapin, and if you can convince me that this proposed legislation is going to in any way abridge the rights of those who are fond of good things to eat, I am "agin" it. I am not so particular about red snapper as I am about canvas-back duck or terrapin. I could even spare the reed bird, but I shall insist upon all the other good things mentioned in your letter, and am opposed to any interference with their free use. While I am fond of Boston baked beans, and not particularly opposed to brown bread, yet I would not surrender a well prepared sirloin steak for either. I am not very familiar with the history and characteristics of Isaak Walton, yet I believe he was called an "angler" and his name has become immortal on account of his relation to his writings setting forth the delights of fishing, and charming those who have never become familiar with such recreation, by his works. I am one of those who have known very little about fishing-scarcely knowing how to put a worm on a fish hook-yet I have always had a fondness for shad in the spring and for white fish almost any time, and am, therefore, against any bill which would interfere with the freedom of those who are fond of fishing as a recreation-or of eating a good fish as a food.

So you may gather from what I have said that $I$ am with you as against any legislation which will in any degree circumscribe the advancement of science or the enjoyments of eating meats or fish as a food.

$$
\text { Very truly yours, S. M. Cullom. }
$$

\section{Proper Title of a Medical Officer of the Army.}

Groveland, Mass., May 4, 1896.

To the Elitor:-I notice in the Journal of February 1 an article entitled "Some Remarks about Asepsis in Military Service," read, etc., by Lieut.-Col. 